Pamiętnik Literacki 2021, 3, s. 31-52
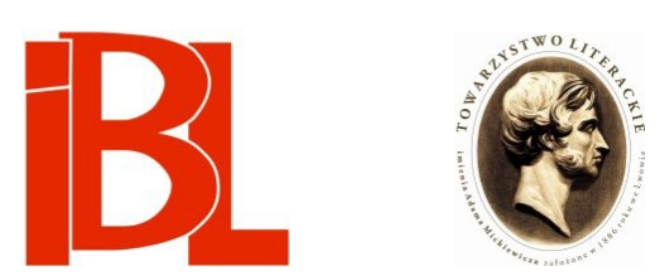

Gdy „ciało w ducha, a duch powraca w ciało". Wątki eschatologiczne w plastyce Norwida

Edyta Chlebowska 
Pamiętnik Literacki CXII, 2021, z. 3, PL ISSN 0031-0514

DOI: $10.18318 / \mathrm{pl} .2021 .3 .2$

EDYTA CHLEBOWSKA Katolicki Uniwersytet Lubelski Jana Pawła II

\section{GDY „CIALO W DUCHA, A DUCH POWRACA W CIALO” WĄTKI ESCHATOLOGICZNE W PLASTYCE NORWIDA}

Fascynacja człowiekiem i jego życiem w wymiarze jednostkowym (indywidualnym) i społecznym (ponadindywidualnym) znajdowała wyraz zarówno w utworach literackich i listach Cypriana Norwida, jak i w jego dziełach o charakterze filozoficznym. Stefan Sawicki pisał:

Norwid, człowiek i poeta, był [...] bardzo wrażliwy na wszystko to, co jest życiem [...]. Ale równocześnie nieustannie myślał o śmierci, oswajał się z jej realnością, ujawniał jej sens. Stale napotykamy w jego utworach motywy śmierci, ludzi, którzy odeszli, wciąż odnajdujemy w jego listach uwagi i dygresje włączające zjawisko śmierci w obręb rozmowy z przyjaciółmi ${ }^{1}$.

Spostrzeżenia uczonego możemy bez obaw rozciagnąć na twórczość plastyczną Norwida, jej zwornikiem jest bowiem „rzecz ludzka”, wyłączny przedmiot gestu artystycznego. Na niezliczonych „karteczkach i złamkach” kreślił twórca litografii Solo realne i imaginacyjne wizerunki postaci współczesnych oraz historycznych, by za ich pośrednictwem wpatrywać się w oblicze „wiecznego człowieka”. Ilustrował tematy literackie i historyczne, ze szczególnym upodobaniem inspirując się Biblią². Nietrudno przy tym zauważyć, że w sensie ikonograficznym artysta właściwie nie interesował się otoczeniem człowieka, stąd brak w jego spuściźnie samodzielnego pejzażu czy widoku architektonicznego, a scenerie kompozycji figuralnych poddane są zazwyczaj daleko idącej redukcji.

Podobnie jak w poezji, także w rysunkowej oraz graficznej twórczości Norwida nieodłącznym elementem refleksji nad biegiem ludzkiego życia była myśl o przemijaniu. Nie odnajdziemy w niej wszakże - jak można się spodziewać, biorąc pod uwagę popularność scen „u łoża śmierci” w XIX-wiecznej ikonografii ${ }^{3}$ - przedstawień korespondujących z ,poetycką suitą nekrologiczną" Czarne kwiaty (DW-7 41-574). Jedne $z$ najsłynniejszych realizacji wspomnianego tematu, bliskie Norwidowi pod

1 S. S a wi cki, O „Śmierci” Cypriana Norwida. W: Norwida walka z formą. Warszawa 1986, s. 83.

2 Zob. A. M elb e chow s k a - Lu ty, Sztukmistrz. Twórczość artystyczna i myśl o sztuce Cypriana Norwida. Warszawa 2001, s. 213-279. - E. C hle b ow s k a, Norwid wobec ilustracji i sztuki ilustratorskiej. „Sztuka Edycji” 2013, nr 2.

3 Zob. A. Pi eń k o s, U łoża śmierci-egzamin prawdziwego realisty. W: Okropności sztuki. Nowoczesne obrazy rzeczy ostatecznych. Gdańsk 2000.

4 W ten sposób odsyłam do nieukończonej, zaplanowanej na 17 tomów lubelskiej edycji Dzieł wszystkich C. N or wi d a. Ponadto posługuję się następującymi skrótami: K = E. Chle b o w s ka, Cyprian Norwid. Katalog prac plastycznych. T. 1-5. Lublin 2014-2020. - PW = C. N o r w id, Pisma wszystkie. Zebrał, tekst ustalił, wstępem i uwagami krytycznymi opatrzył J. W. Go mu licki. T. 1-11. War- 
względem techniki wykonania i typu obrazowania, pozostawił rówieśnik poety Teofil Kwiatkowski, autor akwarelowych kompozycji ukazujących ostatnie chwile z życia Fryderyka Chopina w otoczeniu kilku osób oraz twórca pośmiertnych wizerunków kompozytora ${ }^{5}$. W spuściźnie Norwida bodaj jedynym tego rodzaju przykładem jest skromny rysunek Spóźniony list - kameralna scena stanowiąca wyraz uogólnionej refleksji na temat śmierci jako siły niszczacej doczesne „tu i teraz”, przecinającej bieg ludzkiego żywota ${ }^{6}$.

W myśli i twórczości Norwida motyw nagłej, przedwczesnej śmierci, wywodzący się $z$ antyku, ustępuje miejsca chrześcijańskiej koncepcji dopełniającego zgonu, której najsłynniejszą realizację odnajdziemy w Fortepianie Szopena, „poetyckim mini-traktacie o dopełnieniu"7. Beata Wołoszyn, analizując różne toposy śmierci, uznała, że motyw śmierci jako dopełnienia stanowi „najbardziej samodzielny nurt w przemyśleniach poety na temat ostatecznych przeznaczeń człowieka"8 . Rozmaite warianty tego motywu reprezentowane sa licznie w poezji, prozie i listach autora epitafium Na zgon śp. Józefa Z. [...], z kolei w odniesieniu do twórczości rysunkowej Norwida możemy mówić nie tyle o bezpośrednich wizualizacjach motywu, ile raczej o śladach podążania wskazanymi tropami myślowymi. Na uwagę zasługuje w tym kontekście symboliczna scena Śmierć, starzec i dziecko z Albumu dla Teodora Jełowickiego (K-1 508, poz. 188/V), łącząca się ze spopularyzowanym w sztuce XVI w. tematem etapów życia ludzkiego, ujmowanych na ogół w formie przedstawień alegorycznych ${ }^{9}$. W twórczości Norwida przybrał on formę m.in. figuralnej sceny Trzy pokolenia, ujętej w antykizowany kostium (il. 1; K-3 186, poz. 544), oraz rysunku Sześć scen $z$ życia ludzkiego, na który składają się niewielkie scenki z podpisami rozpoczynającymi się od zwrotu „uczy się” (il. 2; K-3 94, poz. 502). W tym na poły żartobliwym rysunku, jakich niemało w plastycznej spuściźnie poety, momenty wzniosłe sąsiadują $z$ zupełnie błahymi, a kwestie egzystencjalne - $z$ salonową codziennością. Ostatni akord biografii bohatera Norwidowskiego cyklu, ujęty w widoku zamkniętej trumny, został opatrzony podpisem „uczy się być zupełnie wy-

szawa 1971-1976. Liczba po dywizie oznacza tom, a po spacji - stronicę. Wyjątkowo w funkcji podkreślenia w cytatach z Dzieł wszystkich pozostawiono kursywę, którą wprowadzili edytorzy.

5 Zob. A. Melbechowska-Luty, Teofil Kwiatkowski (1809-1891). Wrocław 1966, s. 69-73.

6 Rysunek znajdował się niegdyś w albumie Z. Krasińskiego (DW-10 131). Na karty albumu Umarli żywi T. Le na r tow i c za trafiły z kolei dwa oparte na obcych wzorach rysunki Norwida, przedstawiające śmiertelne wizerunki bł. Jozafata (K-3 82, poz. 496) i abp. M.-D.-A. Siboura (K-3 84, poz. 497).

7 B. W oł o s zy n, Norwid ocala. Heroizm, śmierć i zmartwychwstanie w twórczości postromantyka. Kraków 2008, s. 225.

$8 \quad$ Ibidem. Zob. też W. B o r o wy, Główne motywy poezji Norwida. W: O Norwidzie. Rozprawy i notatki. Warszawa 1960, s. 49. - A. Merda s, „Człek od niej starszy”. „Znak” 1977, nr 4, s. 433. S. S a wi cki, Z zagadnień semantyki poetyckiej Norwida. W: Norwida walka z forma, s. 35.

9 Zob. G. Mi n o is, Historia starości. Od antyku do renesansu. Przeł. K. M a r c z e w s k a. Warszawa 1995. - Ph. Ariè s, Historia dzieciństwa. Dziecko i rodzina w czasach ancien régime'u. Przeł. M. O c hab. Warszawa 2010, s. 43-45. Wśród najsłynniejszych realizacji owego tematu można wymienić takie płótna, jak: Gi o r gi o n e, Trzy etapy życia ludzkiego (1500-1510, Palazzo Pitti, Florencja); Ty cj a n, Alegoria życia (Trzy etapy życia ludzkiego) (1512-1514, National Gallery of Scotland, Edynburg); H. B ald ung G r i e n: Trzy etapy życia kobiety (1540-1543, Museo Nacional del Prado, Madryt), Siedem etapów życia kobiety (1544, Museum der Bildenden Künste, Lipsk). 
kształconym". Niedokonana forma czasownika - zastosowana zarówno w tym, jak i w innych podpisach - ujawnia organizującą rysunkową całość myśl, że w ziemskiej doczesności, in statu viae, człowiek nie jest w stanie osiagnąć pełni. Za komentarz do tego rysunku niech posłuży cytat z Krakusa: „Dochodzić - trud, / A dojść - jest cud" (DW-5 194). Wskazuje on na potrzebę łaski Bożej, stanowiącej warunek dopełnienia ludzkiego żywota, które może się dokonać wyłącznie w sferze transcendencji. W twórczości Norwida myśl ta łączy się z problematyką męczeństwa, będąca istotnym aspektem rozbudowanej refleksji na temat pierwszych wieków chrześcijaństwa ${ }^{10}$. W realizacjach plastycznych artysta unika jednak bezpośrednich obrazów cierpienia i śmierci. Bohaterowie pokaźnej kompozycji rysunkowej Christiani ad leones świadczą przede wszystkim swoją postawą, z jednej strony nieulękłą i ufną, a z drugiej - pełną dobroci i łagodności (K-3 182, poz. 542). Ważniejszym niż świadectwo krwi aspektem świętości pierwszych chrześcijan jest dla Norwida świadectwo wiary, głoszonej przed obliczem oskarżycieli - zbliża to artystę do pierwotnego rozumienia pojęcia męczeństwa, które w pierwszych wiekach chrześcijaństwa oznaczało, zgodnie $z$ tradycją grecką, dawanie świadectwa, głoszenie orędzia Chrystusa ${ }^{11}$. Podobne rozumienie sensu męczeństwa zawarł Norwid w wierszu Dwa męczeństwa, zestawiającym kilka epizodów z biografii Apostoła Narodów ${ }^{12}$. Przywołanym przykładom patronuje myśl św. Pawła, którego dzieje, spuścizna oraz misja stanowiły źródło inspiracji dla licznych dzieł autora dramatu Słodycz: „Dobrym bój bojował, biegiem wykonał, wiaręm zachował" $(2 \mathrm{Tm} 4,7)^{13}$.

Rysunek Christiani ad leones prowadzi nas wprost do problematyki eschatologicznej, żywotnie zajmującej nie tylko Norwida poetę i myśliciela, ale w istotnym stopniu dopełniającej również Norwidowską ikonografię skupioną wokół życia i śmierci człowieka. Na szczególną uwagę zasługuje w tym zakresie kilka dzieł rysunkowych i graficznych $z$ lat pięćdziesiatych XIX stulecia, odnoszących się do

10 Problematyka męczeństwa w twórczości literackiej Norwida doczekała się wielu omówień - zob. np. I. Sła w ińs ka, Chrześcijaństwo w przemyśleniach Norwida. „Znak” 1966, nr 6, s. 729. - J. S ali j, Problem męczeństwa u Norwida. W zb.: Norwid a chrześcijaństwo. Red. J. F e rt, P. Chleb ow s ki. Lublin 2002. - W oło s zy n, op. cit., s. 51-167.

11 Termin „męczeństwo” pochodzi od greckiego „martýrion”, oznaczającego “świadectwo złożone pod przysięgą i mające wartość próby'. Zob. A. Ku b i ś: Chrześcijańska idea męczeństwa. „Analecta Cracoviensia” t. 2 (1970), s. 305 n.; Męczeństwo a Kościół. „Kieleckie Studia Teologiczne” 2002, nr 1/2, s. 95 n. - Słownik teologii biblijnej. Red. X. Lé on-D u fou r. Przeł., oprac. K. Ro maniuk. Warszawa 1973, s. 472. - E. Ło mnicki, Męczeństwo jako znak prawdziwości religii chrześcijańskiej $w$ ujęciu apologetów starochrześcijańskich. „Tarnowskie Studia Teologiczne” t. 7 (1979), s. 75.

12 Zob. Salij, op. cit., s. 41-51. - Wołoszyn, op. cit., s. 112-121. - P. Ma r c h ew ka, Z romantycznych rodowodów biblijnych. Apostoł Paweł w twórczości Cypriana Norwida. Poznań 2009, s. $123-190$.

13 Cytaty z Pisma Świętego podaję według Biblii gdańskiej (Biblia, to jest całe Pismo Święte Starego i Nowego Testamentu, z hebrajskiego i greckiego języka na polski pilnie $i$ wiernie przetłumaczona. Warszawa, b. r.). Jak zauważyła A. M erd a s (Łuk przymierza. „Biblia” w poezji Norwida. Lublin 1983, s. 31), Norwid bardzo dobrze znał Pismo Święte. Chętnie przytaczał teksty biblijne, opatrując je adresami bibliograficznymi, ale nierzadko cytował również z pamięci, opierając się na różnych wydaniach. Uczona podkreśliła, że choć najczęściej poeta sięgał do Biblii gdańskiej, to w interpretacji pozostawał wierny egzegezie katolickiej. Inspiracje osobą i dziełem Tarseńczyka w twórczości Norwida omówił Marchewka (op. cit.). 
chrześcijańskiej nauki o zmartwychwstaniu wszystkich ludzi na końcu czasów. W latach 1853-1854, w trakcie pobytu poety w Ameryce, powstały trzy kompozycje, które przedstawiają powstające $\mathrm{z}$ grobów i wznoszące się ku niebu postacie w zwiewnych antykizowanych szatach; w literaturze przedmiotu prace te funkcjonuja pod nieco mylacymi tytułami Dusze ulatujace z mogit i Dusze ulatujace $z$ mogit do nie$b a^{14}$. Nie ma najmniejszej wątpliwości, że na rysunkach ukazane zostały nie dusze, lecz ciała, a ściślej - ciała zmartwychwstałe. Ruch wstępujący mają podkreślać ich wyprostowane sylwetki, uniesione ręce oraz twarze zwrócone ku górze ${ }^{15}$. W każdej z omawianych scen pojawiają się także osoby dopiero opuszczające miejsce swojego pochówku. Na rysunku, który Józef Czapski ofiarował paryskiemu Zakładowi św. Kazimierza, to właśnie one stanowią główną oś zainteresowania artysty (il. 3; K-3 414, poz. 651). W centrum przedstawienia widzimy młodą kobietę wychodząca spod uniesionej płyty nagrobnej, a tuż obok drugą postać wyłaniającą się zza innego nagrobka ${ }^{16}$. Dopiero na dalszym planie pojawiają się sylwetki, które $z$ lekkością i bez doczesnych ograniczeń wznoszą się ponad ziemię. Z kolei na dwóch pozostałych pracach - w tym na wykreślonym nader precyzyjnie piórkowym rysunku ze zbiorów Muzeum Narodowego w Warszawie (il. 4), co nasuwa przypuszczenia, że mógł on być pomyślany jako projekt przyszłej pracy graficznej lub jako wizytówka umiejętności w owym zakresie ${ }^{17}$ - przedstawieni są głównie ludzie, zarówno dorośli, jak i dzieci, którzy wznieśli się już ponad ziemię (K-3 402, poz. 646). Lawowany akwarelą rysunek - podarowany przez poetę Teofilowi Lenartowiczowi i zachowany w albumie Umarli żywi - prezentuje nadto bardzo interesujacy zabieg kompozycyjny, silnie powiązany z semantyką dzieła (il. 5; K-3 52, poz. 481). Otóż przedstawienie zostało rozdzielone na dwie części przebiegającą diagonalnie krawędzią cmentarnego muru, od którego w stronę widza odchodzi dozorca cmentar-

14 Na potrzeby rozmaitych opracowań i publikacji pozbawione werbalnych znaczników dzieła Norwida $z$ reguły opatrywano tytułami pochodzącymi od badaczy lub edytorów, nierzadko istotnie się od siebie różniącymi nawet na poziomie podstawowych ustaleń, np. deszyfracji tematu. W przypadku omawianych kompozycji odnotowano również inne tytuły: Scena alegoryczna na cmentarzu (K-3 52, poz. 481), Dozorca cmentarny (K-3 402, poz. 646), Mężczyzna przy furcie w murze (K-3 414, poz. 651). Problematyka symbolicznego gestu „spojrzenia ku niebu” w twórczości Norwida, gestu będącego wyrazem zwrócenia się do Boga, zapatrzenia w wieczność, doczekała się niemałej literatury przedmiotu, której punkt wyjścia stanowiły interpretacje poematu Assunta. Zob. M. M a c i ej ew s ki, Spojrzenie „w górę” i „wokoło” (Norwid - Malczewski). „Roczniki Humanistyczne” 1976, z. 1, s. 244-247. - Z. Li s ow s ki, Motyw krzyża w twórczości Norwida. „Przegląd Powszechny” 1984, nr 6. - G. Króli ki e w i c z, Terytorium ruin. Ruina jako obraz i temat romantyczny. Kraków 1993, s. 131. - K. Trybuś, „Assunta” jako poemat metafizyczny. „Studia Norwidiana” t. 11 (1993). Niezależnie od wymiaru eschatologicznego J. C z a p s k i (list do K. Zachwatowicz i A. Wajdy, z 8 XII 1987. W: J. Czaps ki, A. W ajd a, K. Z a c hw a t ow i c z, Korespondencja. „Zeszyty Literackie” t. $132\langle 2015, \mathrm{nr} 4\rangle$, s. 136) interpretował tę scenę jako alegorię Polski zmartwychwstałej.

17 Na taką geneze powstania rysunku może wskazywać to, że trafił on do rąk C. E. Doeplera, kierującego nowojorska pracownią graficzną, w której Norwid był zatrudniony w miesiącach letnich 1853 r. przy opracowywaniu plastycznym monumentalnego almanachu wystawy powszechnej: The World of Science, Art and Industry Illustrated from Examples in the New York Exhibitions, 1853-1854. With 500 illustrations. Under the superintendence of C. E. Döpler. Ed. B. Silliman Jr, Ch. Rush Goodrich. New York 1854. Niewykluczone, że twórca Solo zaprezentował tę kompozycję $\mathrm{w}$ trakcie starań o pracę rysownika w owym zespole. O wspomnianym epizodzie $z$ artystycznego życiorysu Norwida pisze Melbechowska-Luty (Sztukmistrz, s. 110-111). 
ny $z$ kluczem w dłoni. Za murem rozgrywa się natomiast zasadnicza scena zmartwychwstania. Znamienne, że w odróżnieniu od kolorów ziemi, dominujących w dolnej partii kompozycji, została ona lawowana błękitną akwarelą. Symboliczne rozdzielenie strefy ziemskiej i niebiańskiej, profanum i sacrum, podkreśla temporalny wymiar zdarzenia, które wypełni się dopiero po przemianie doczesnej postaci wszystkich ludzi. Jak głosił św. Paweł, zmarli zostaną przebudzeni w chwili ponownego przyjścia Chrystusa jako pierwsi, przed tymi, których paruzja zastanie przy życiu (1 Tes 4, 14-17) ${ }^{18}$. Przedstawicielem żyjących jest na rysunku Norwida pierwszoplanowy bohater - dozorca, w którego sylwetce łączą się obie barwy: niebieska i brazowa.

Po kilku latach Norwid ponownie pochylił się $\mathrm{z}$ ołówkiem i rylcem nad tajemnica wskrzeszenia wszystkich zmarłych, komponując, a następnie dwukrotnie utrwalając na metalowej płycie wyobrażenie powstającej z grobu kobiety, znane pod tytułem Alleluja, zapisanym w formie inskrypcji na porzuconym na ziemi kamiennym ułomku (K-5 470-476, poz. $1100\langle$ Alleluja I〉, $1101\langle$ Alleluja II〉). Stanowiący scenerię wydarzenia cmentarz to - podobnie jak na wcześniejszych rysunkach - niepozorna nekropolia ze skromnymi nagrobkami i chylącymi się ze starości krzyżami, ale tym razem Norwid ulokował miejsce chrześcijańskiego pochówku $\mathrm{w}$ cieniu majestatycznych ruin greckiej świątyni ${ }^{19}$. Wąski kadr ujęty w formę stojącego prostokąta obejmuje niewielki fragment cmentarza, nad którym unosi się dmący w trąbę anioł (il. 6) lub trzy anioły wychylające się zza spękanego frontonu antycznej budowli (il. 7) ${ }^{20}$. W tej kompozycji - inaczej niż w przypadku rysunkowych realizacji tematu - widzimy tylko jedną osobę doznająca przemiany oczekiwanej u końca czasów. Jest to młoda kobieta o natchnionym wyrazie twarzy, budząca się ze śmiertelnego odrętwienia na dźwięk „trąby zmartwychwstania”.

Zainteresowanie twórcy Solo problematyka powszechnego zmartwychwstania, zobrazowaną na rysunkach i grafikach powstałych w pierwszej połowie lat pięćdziesiątych XIX stulecia, niewątpliwie miały źródło w fascynacji osobą i nauczaniem św. Pawła. Jak zauważył omawiający Norwidowskie „pisma z Tarseńczykiem" Piotr Marchewka:

Zapewne gdzieś na przełomie lat 40/50 musiało dojść do „intensywniejszego” zetknięcia Cypriana Norwida z Pawłem Apostołem, jego twórczością i teologią, z biografią i legendą (lektura Dziejów Apostol-

Zob. J. Stę pi eń, Eschatologia św. Pawła. „Studia Theologica Varsaviensia” t. 1 (1963), s. 75. H. Langk a mmer, Naczelne tematy eschatologii św. Pawła (paruzja, powszechne zmartwychwstanie, nowe stworzenie). „Roczniki Teologiczno-Kanoniczne” 1981, z. 1, s. 66. - J. D e cy k, Eschatologiczna myśl św. Pawła Apostoła inspiracja dla posoborowej liturgii pogrzebu. „Studia Płockie" t. 37 (2009), s. 52.

19 B. Bilińs ki (Norwid $w$ Rzymie. W zb.: Cyprian Norwid $w$ 150-lecie urodzin. Materiały konferencji naukowej 23-25 września 1971. Red. M. Żmi grodzka. Warszawa 1973, s. 160) rozpoznał na rycinie ruiny świątyni Hery (tzw. Herajon II) w Paestum, uznawanej niegdyś za świątynię Posejdona. Por. rysunek C. Norwida Światynia $w$ Paestum (K-3 210, poz. 554), przedstawiający ruiny tej samej świątyni w odmiennym ujęciu.

20 Norwid wykonał dwie wersje akwaforty, powstałe na podstawie niemal identycznej kompozycji, różniące się sposobem opracowania rysunku oraz szeregiem detali. Poza najbardziej znaczącymi, wspomnianymi różnicami w przedstawieniu aniołów dotyczą one rozmieszczenia i liczby krzyży cmentarnych, roślinności, szczegółów stroju kobiety. 
skich, pism Ojców Kościoła 〈zwłaszcza Historii Kościoła Euzebiusza z Cezarei〉, żywotów i legend, spotkania $\mathrm{z}$ ludźmi zauroczonymi postacią św. Pawła) ${ }^{21}$.

Badacz odnotował, że „tak jak w latach pięćdziesiątych sięgał Norwid najczęściej po imię i przydomki Pawła $z$ Tarsu, tak też wtedy najchętniej przywoływał Corpus Paulinum" ${ }^{22}$. Lektura listów Pawłowych, w których silnie reprezentowane są tematy eschatologiczne, wyrastające z głębokiego przeżycia chrystofanii pod Damaszkiem, stała się dla poety nie tylko źródłem refleksji dotyczącej końca czasów, ale również punktem wyjścia formuł ikonograficznych zastosowanych $\mathrm{w}$ interesujących nas przedstawieniach ${ }^{23}$. Apostoł Narodów wyraził w listach głębokie przekonanie pierwotnego Kościoła, że ,jako w Adamie wszyscy umierają, tak i w Chrystusie wszyscy ożywieni będą" (1 Kor 15, 22). Zbawiciel jest nie tylko źródłem nowego życia, lecz także wzorem ostatecznego przeobrażenia, do którego dojdzie, kiedy „sam Pan z okrzykiem, z głosem archanielskim i z trąbą Bożą zstąpi z nieba, a pomarli w Chrystusie powstana najpierwej. Zatem my żywi, którzy pozostaniemy, wespół $\mathrm{z}$ nimi zachwyceni będziemy $\mathrm{w}$ obłokach naprzeciwko Panu na powietrze, a tak zawsze z Panem będziemy" (1 Tes 4, 16-17). Zwracając się do wiernych, św. Paweł posługiwał się obrazami ówczesnej apokaliptyki, aby „uwydatnić potężne i ostateczne wkroczenie Boga w dzieje świata w ich fazie końcowej”" ${ }^{24}$. $Z$ perspektywy wierzących paruzja stanowić ma dopełnienie chrześcijańskiej egzystencji, w sposób ostateczny urzeczywistniając związek wiernych z Chrystusem, w którego chwale będą oni mogli odtąd uczestniczyć, oglądając Boga "twarzą w twarz" ${ }^{25}$. W opisach powtórnego przyjścia Zbawiciela św. Paweł podkreśla zmartwychwstanie ciał, paruzja stanowi bowiem nade wszystko triumf nad śmiercią ${ }^{26}$. Wskrzeszone do życia wiecznego ciało każdego człowieka, którego przemianę Tarseńczyk przedstawia za pomoca porównań, nazywając je „ciałem duchowym” (1 Kor 15, 35-49), za sprawą Ducha Bożego zostanie ukształtowane na wzór ciała Chrystusa Zmartwychwstałego. Wskutek tej przemiany człowiek ziemski ustapi miejsca „człowiekowi niebieskiemu" (1 Kor 15, 49).

Norwidowskie wyobrażenia zmartwychwstałych, głęboko zakorzenione w naukach św. Pawła, kreślącego przed chrześcijanami obrazy eschatologicznej nadziei, stanowią swoiste wyznanie wiary i owoc pogłębionej refleksji nad problematyką, której poeta poświęcił tekst napisany w 1851 lub 1852 r. w formie zbioru notatek, przygotowywanych być może do jakiegoś pełniejszego opracowania. Po raz pierwszy tekst ten został opublikowany przez Zenona Przesmyckiego jako [Zmartwychwstanie narodul ${ }^{27}$, a następnie przez Juliusza Wiktora Gomulickiego, który zmienił

Marchewka, op. cit., s. 217.

Ibidem.

Zob. Langkammer, op. cit. - A. J a nkowski, Eschatologia biblijna „Nowego Testamentu”. Kraków 1987, s. 74-87.

Langka m m e r, op. cit., s. 67.

Zob. np. U. Grzy m ska, Radosny aspekt paruzji $w$ listach św. Pawła do Tesaloniczan. „Ruch Biblijny i Liturgiczny” 1994, nr 4. - J. K u c i c k i, Paruzja Jezusa Chrystusa. Poczatki eschatologii nowotestamentalnej $w$ listach do Tesaloniczan. Warszawa 2009. - A. D a ń c z a k, Transcendencja końca. Pytanie o relacje paruzji i śmierci człowieka. „Collectanea Theologica” 2011, nr 3.

Zob. St ępi eń, op. cit., s. 76-77.

„Kultura” 1931, nr 4. 
tytuł na [Zmartwychwstanie historyczne] (PW-6 609-617) ${ }^{28}$. Sawicki zwrócił ostatnio uwagę, że problematyka tekstu nie ogranicza się do horyzontu historycznego, lecz łączy „zmartwychwstanie historyczne” ze zmartwychwstaniem eschatologicznym, i zaproponował $\mathrm{z}$ kolei nazwę bardziej ogólną: [O zmartwychwstaniu i zbawieniu ${ }^{29}$. Uczony stwierdził wprost:

zmartwychwstanie historyczne jest dla Norwida jakby przedświtem zmartwychwstania eschatologicznego. Poprzedza ono i przybliża to zmartwychwstanie, a także związane $z$ nim zbawienie człowieka, które jako rezultat przezwyciężenia śmierci przez Chrystusa jest w terminologii teologicznej Łaską ${ }^{30}$.

Nie bez przyczyny Norwid określił zmartwychwstanie historyczne mianem promienia „przez szczeliny zza te go - ś w i a ta wnikającego” (PW-6 609), oświetlającego tę prawdę wiary, o której szczerze wyznawał:

Jak się dzieje sprawa indywidualnego zmartwychwstania? - o tym jeszcze na pewno niewiele mówić się nam godzi - wszakże dla nas, Chrześcijan, którzy w zmartwychwstanie ciał wierzymy, do pewnego stopnia i te odkryć się mogą tajemnice, zwłaszcza iż Duchowi wolno jest badać ws zystko, nawet wnętrzności ducha, jeśli to się w trzeźwej sprawie Bożej, a nie z płonnej czyni ciekawości. [PW-6 610]

W kontekście rysunkowych i graficznych przedstawien zmartwychwstania warto przyjrzeć się dalszym rozważaniom poety. Powołując się na św. Pawła, podkreślałon, że „inne jest ciało-śmiertelne, a inne ciało-nieśmierte ln e" (PW-6 612). Zgodnie z przekonująca argumentacją badacza tropów Pawłowych w twórczości Norwida poeta dokonał tu swoistej kontaminacji terminologii i semantyki Apostoła Narodów, który w Pierwszym Liście do Koryntian $(15,44)$ pisał: „Jest ciało cielesne, jest też ciało duchowne”. Wynika stąd, że poeta - podobnie jak św. Paweł - utożsamiał cielesność ze śmiertelnością, a ducha z nieśmiertelnością ${ }^{31}$. Wspominając o światłości jako „wyrobie zmartwychwstania”, autor Vade-mecum odwołuje się - jak można sądzić - do katechizmowej nauki o przymiotach ciał zmartwychwstałych, zakorzenionej w teologii św. Tomasza z Akwinu ${ }^{32}$. Wedle wprowadzonego przez Akwinatę rozróżnienia spośród cech ciała zmartwychwstałego jedna tylko właściwość - nieśmiertelność - wspólna jest świętym i potępionym, pozostałe natomiast charakteryzuja wyłącznie ciała świętych, a są to: niecierpiętliwość (wolność od doświadczenia cierpień, bólu i dolegliwości), jasność, lekkość (pozba-

Zob. też J. W. Go muli cki, Metryki i objaśnienia. PW-7 630.

S. S a w i cki, Czy Norwid wierzyt w zbawienie powszechne? W: Wartość - sacrum - Norwid. 3. Studia i szkice aksjologicznoliterackie. Lublin 2017, s. 182. Kwestię dwutorowości rozważań poety w omawianym tekście podjęła też W ołoszyn (op. cit., s. 251), skupiła się jednak na problematyce zmartwychwstania historycznego, oznaczającego zmartwychwstanie „zarówno jednostek, jak i społeczeństw, w tym także narodów, widziane w perspektywie historii zbawienia”. Badaczka podkreśliła nadto, że u podstaw Norwidowskiej refleksji o zmartwychwstaniu leży przeświadczenie o istotnym udziale każdego człowieka w historii świata (ibidem, s. 252; zob. też s. 253-276).

S a w i c ki, Czy Norwid wierzyt w zbawienie powszechne?, s. 184.

Zob. Marchewka, op. cit., s. 103-104. Badacz formułuje wnioski na podstawie analizy Norwidowskiego nawiązania do poglądów św. Pawła we wstępie do poematu Niewola (1849), by następnie rozszerzyć je na interesujacy nas fragment [Zmartwychwstania historycznego].

Św. Tomasz z Akwinu, Suma teologiczna. T. 33: Zmartwychwstanie ciat. (Suppl. 69-86). Przekł., objaśn., skorowidz P. B ełch. London 1983, s. 187-242 (zagadnienia 82-85). Na stronie: http://www.katedra.uksw.edu.pl/suma/suma_indeks.htm (data dostępu: 14 X 2020). 
wienie ciężaru, który przygniata ciało, dzięki czemu może być ono swobodnie przenoszone przez duszę), subtelność (całkowite poddanie ciała pod rozkazy duszy) ${ }^{33}$. W [Zmartwychwstaniu historycznym] Norwid wskazuje na jeden $z$ tych przymiotów: jasność, ale wykorzystuje do swych rozważań stosowaną przez św. Pawła perspektywę „,kosmiczna”, zgodnie z która „inna jest chwała Słońca, a inna chwała Księżyca” (PW-6 610) ${ }^{34}$. Poeta - podążając być może śladem Ojców Kościoła - terminologie astronomiczna zastosował tu w odniesieniu do ciał ludzi świętych i ciał grzeszników ${ }^{35}$. Istotny wydaje się pewien wątek pojawiający się w kontekście przytoczonych słów, $z$ jednej strony stanowiący potwierdzenie wskazanej sugestii, $z$ drugiej natomiast prowadzący do dalszych rozważań poświęconych Norwidowskim wizualizacjom momentu zmartwychwstania. Chodzi o przywołanie przez twórce Solo tradycji sztuki chrześcijańskiej, która „przewidziała to w świętym swym natchnieniu i otacza do dziś głowy świętych globem złotej światłości" (PW-6 611). Owa światłość nie należy - co poeta dobitnie podkreślał „Z wiarą na jaką stać nam” (PW-6 611) - do porządku retorycznego, lecz eschatologicznego. Światłość jest nieodłącznym atrybutem tych, którzy dostępuja zabawienia, pochodzącym wprost od Chrystusa, ,jedynego Dawcy światłości” ${ }^{36}$. Wyraźnym śladem zapatrzenia w sztukę sakralną powstała „na katakumbach, na grobach męczenników, krwia prawie ofiar tych na ścianach zawiązujących się kościołów" jest również kończący tę część rozważań nad zmartwychwstaniem obraz: „Z kropli tych, z kół tych złotych, z glorii tych, $z$ duchów tych w chwale zmartwychwstania sklepi się firmament wnętrza Niebios" (PW-6 611-612). Owa wizja wydaje się wprost zaczerpnięta $z$ malarstwa włoskiego trecenta ${ }^{37}$ bądź z nieco późniejszej twórczości Fra Angelica ${ }^{38}$, którego Norwid uważał za „najwięcej chrześcijańskiego malarza, jakiego znamy” (DW-3 222).

Podobnie jak [Zmartwychwstanie historyczne], powstałe trochę później „amerykańskie" rysunki oraz akwaforty Alleluja I i Alleluja II ujawniają, że artystę głę-

Zob. J. Ga u me, Zasady i całość wiary katolickiej, czyli wykład jej historyczny, dogmatyczny, moralny, liturgiczny, apologetyczny, filozoficzny $i$ socjalny od stworzenia świata aż do naszych czasów. Wyd. 2, oddz. 2 (t. 3-4). Warszawa 1857, s. 173-174.

Według św. Pawła ciało zmartwychwstałe będzie niezniszczalne, chwalebne, mocne i duchowe - zob. J an kowski, op. cit., s. 76. Pośród tych cech apostoł nie wymienia jasności, stąd sugestia, że Norwid nawiązuje w swych przemyśleniach do ujęcia katechizmowego, opartego na teologii tomistycznej.

35 Zob. Marchewka, op. cit., s. 105. Zob. też Pismo Święte Nowego Testamentu. T. 7: Listy do Koryntian. Wstęp - przekład z oryginału - komentarz. Oprac. E. Dą browski. Poznań 1965, s. 282.

36 Św. Augu sty n, O Trójcy Świętej. Przeł. M. St ok ow s ka. Oprac. J. M. Szy mu sia k. Poznań 1962, s. 174. C. Norwid (Do Pani na Korczewie. PW-1 350) pisał zaś:

Mistrzem jest tylko ten, który

Odszedł daleko:

By kiedyś wrócił na obłokach, $z$ góry,

Światłości-rzeką.

37 Na uwagę zasługują w tym kontekście zwłaszcza wizerunki tronującej Madonny w otoczeniu aniołów i świętych (tzw. Maestà) autorstwa D. di Buoninsegni (1308-1311, Museo dell'Opera del Duomo, Florencja), S. Martini e go (1315-1321, Palazzo Pubblico, Siena) i A. Lor enzetti e go (ok. 1335, Museo di Arte Sacra, Massa Marittima).

38 Np. Koronacja Matki Boskiej z aniołami i świętymi (1432, Galleria degli Uffizi, Florencja), Ottarz z Perugii (1437-1438, Galleria Nazionale dell'Umbria, Perugia), Sacra Conversatione (1434, Museo di San Marco, Florencja). 
boko zajmowały nie tyle okoliczności, ile przede wszystkim natura owej ostatecznej przemiany, wskutek której powstanie do życia „człowiek niebieski”. Kompozycje te odsyłają nas również siłą rzeczy do przymiotów ciała zmartwychwstałego. W postaciach, których sylwetki wbrew prawu ciążenia swobodnie się wznoszą i których idealizowane rysy twarzy wyrażają szczęście oraz błogość, odnaleźć można nie tylko lekkość i jasność, lecz także subtelność, która moca spragnionej obcowania z Najwyższym duszy porywa je ku niebu. $Z$ kolei w wyobrażeniach postaci opuszczających miejsce ziemskiego pochówku poszukiwał Norwid sposobu przedstawienia mającej zajść w momencie zmartwychwstania przemiany, której istotą będzie ponowne połączenie ciała $z$ duszą ${ }^{39}$. Swoje intencje zdradził w krótkim komentarzu do akwaforty Alleluja II, dołączonym do egzemplarza ryciny ofiarowanego Józefowi Ignacemu Kraszewskiemu:

Artysta próbował, czyli podobna jest okazać obliczem, jako pierwsza trą̧a Zmartwychwstania czyni, iż ciało w ducha, a duch powraca w ciało.

Żyjąc albowiem w epoce, w której realizm i idealizm postaciują się, zadanie powyższe uważał za potrzebne empirycznie zgłębić.

Ale - widząc, iż rzecz mu się nie udaje, zniszczył blachę i dlatego rycina taka jest jedna tylko. [DW-12 203]

Można odnieść wrażenie, że krytyczne uwagi na temat kompozycji wraz z informacją o zniszczeniu matrycy graficznej stanowią zabieg autokreacyjny, służący wyeksponowaniu semantycznego aspektu ryciny oraz ważkości jej przesłania. Trudno bowiem przypuszczać, by Norwid zdecydował się ofiarować Kraszewskiemu, skądinąd miłośnikowi sztuki i znanemu kolekcjonerowi, pracę nieudaną. Taką sugestię potwierdzałoby również to, że wbrew ostatnim słowom, podkreślonym w autografie atramentem i czerwoną kredką, ofiarowana twórcy Starej baśni rycina nie była jedynym odbitym $z$ tej płyty egzemplarzem. Jak ustalił Przesmycki, Norwid zachował w swoim archiwum artystycznym - być może w celach dokumentacyjnych - drugą odbitkę, dodatkowo lawowaną akwarelą ${ }^{40}$. Brak natomiast śladów istnienia innych egzemplarzy, co z kolei uprawdopodobnia deklarację, iż artysta zniszczył matrycę.

Wątpliwości tych nie rozwiewa - przeciwnie, zdaje się je pogłębiać - fakt, że grafika powstała w dwóch wersjach datowanych na r. 1857, różniących się sposobem opracowania rysunku oraz pewnymi detalami, ale $z$ pewnością wykonanych według tej samej kompozycji. Najbardziej widoczna różnica dotyczy górnej partii: w wersji dla Kraszewskiego unoszą się trzy anioły, natomiast w „drugiej” wersji widnieje tylko jeden anioł. Trudno rozstrzygnąc, czy - jeszcze przed wysłaniem ryciny Kraszewskiemu - Norwid wykonał, a w następnej kolejności być może zniszczył obie matryce, czy też najpierw opracował wersje przesłaną autorowi Starej

Ta przyjęta za św. Tomaszem interpretacja wiary w zmartwychwstanie, opierająca się na przekonaniu o nieśmiertelności duszy, która po śmierci decyduje o przetrwaniu tożsamości człowieka, obowiazywała w teologii katolickiej do XX wieku. Zob. J. Ratzinger, Eschatologia - śmierć iżycie wieczne. Przeł. M. W ę cła w s ki. Poznań 1985, s. 196-198. - Cz. S. B a r tni k, Dogmatyka katolicka. T. 2. Lublin 2003, s. 877. - T. Dola, Antropologia prawdy wiary „Wierzę $w$ ciała zmartwychwstanie”. „Ethos” 2008, nr 2/3.

40 Z. Prze s m y cki, Materiały do twórczości malarskiej i rysowniczej Cypriana Norwida. Bibl. Narodowa, rkps 6330 III, k. 467r. Zob. K-5 470, 472, poz. 1100. 
baśni, a dopiero po tym zdarzeniu przygotował drugą płytę z niemal identycznym przedstawieniem. Za pierwszą ewentualnością zdaje się przemawiać nie tylko równie znikoma jak w przypadku wersji dla Kraszewskiego liczba egzemplarzy z jednym aniołem (zachowały się dwie odbitki, o dwu kolejnych wspominają źródła) (K-5 474476, poz. 1101), ale i cechy stylistyczne, ujawniające większą swobodę gestu artystycznego w wersji $\mathrm{z}$ trzema aniołami, co przemawia za uznaniem tej grafiki za realizację późniejszą. Nadto różnice w obrębie wizerunku kobiety powstającej z martwych dotyczą głównie jej stroju, natomiast twarz - nie tylko rysy, lecz także jej natchniony wyraz - jest na rycinach niemal identyczna, co również świadczyłoby o powstaniu obu wersji przed sformułowaniem cytowanego odautorskiego komentarza. W innej sytuacji należałoby się spodziewać, że twórca podejmie się na nowo, w odmienny sposób, opracowania fizjonomii bohaterki eschatologicznej wizji. Sugestie te zbieżne są z numerami porządkowymi przypisanymi obu wersjom w literaturze przedmiotu, choć wobec braku bardziej wiążącej argumentacji trzeba je traktować umownie ${ }^{41}$. Pomijając wątpliwości dotyczące chronologii oraz odsuwając na bok krytyczną opinię artysty o własnym dziele i nierozstrzygalną - jak się wydaje - kwestię potencjalnego zniszczenia jednej lub obu gotowych matryc graficznych, chciałabym raz jeszcze przyjrzeć się bohaterce Norwidowskiej akwaforty.

Na wpół przymknięte powieki i wciąż wiotkie, bezwładne ciało sugestywnie przedstawiaja moment graniczny, tuż przed ostatecznym scaleniem duchowo-cielesnej istoty ludzkiej. Rysy twarzy zwracają uwagę wybitnie portretowym charakterem, dalekim od idealizowanych wizerunków znanych z wcześniejszych realizacji rysunkowych tematu zmartwychwstania. Tamte zdawały się odsyłać widza wprost do eschatologicznej jedności wspólnoty wierzących, ta zaś wskazuje na odrębność każdej osoby, która jednocząc się ze wszystkimi zbawionymi, nie traci nic ze swej osobności. Kontynuując tę myśl, można zaryzykować przypuszczenie, że wizerunek młodej kobiety przedstawionej na akwaforcie to zarazem portret konkretnej osoby. Sugestię tę zdaje się potwierdzać fragment listu poety do Michaliny Dziekońskiej Z r. 1852:

Dla osoby, która ma oczy, jakoby słyszała ruch w powietrzu i gwiazd rozruch, i głosy na błękicie niebios, że się właśnie poczęło Zmartwychwstanie!... załączam ode mnie na pamiątkę karteczkę. [DW-10 430]

Tożsamość osoby, którą autor Promethidiona opisał enigmatyczną frazą tak wyraźnie korespondującą z omawianą ryciną, że można ją wręcz uznać za tekstowy odpowiednik graficznego wizerunku, wobec braku bliższych przesłanek nie została ustalona przez żadnego $\mathrm{z}$ edytorów ani badaczy Norwidowskiej epistolografii. Można się jedynie domyślać, że była to kobieta z najbliższego otoczenia Dziekońskiej

J. W. G o mulicki (Dokumentacja ilustracyjna. Objaśnienia. PW-11 362, poz. 213-214) uznał, że rycina z jednym aniołem stanowi pierwszą, a kompozycja ofiarowana Kraszewskiemu drugą wersję omawianej grafiki, aczkolwiek przywołana przez niego argumentacja opierała się na niepełnej wiedzy dotyczącej obu wersji. Taką samą kolejność przyjęła H. Widack a (Grafika Norwida. „Studia Norwidiana” t. 3/4 〈1985-1986〉, s. 163-164) w jedynym jak dotąd całościowym opracowaniu działu Norwidowskiej grafiki. W Katalogu prac plastycznych Norwida analogicznie mowa o rycinach Alleluja I i Alleluja II, z zastrzeżeniem, iż numeracja ma charakter umowny, nie zaś ściśle chronologiczny (K-5 470-476, poz. 1100-1101). 
i Norwida, o czym dobitnie świadczy hermetyczny kod deskryptywny użyty w owej charakterystyce. Nawet jeśli u źródeł wyraźnej analogii istniejącej między dwoma przywołanymi opisami „eschatycznych figur”, pochodzacymi z noty skierowanej do Kraszewskiego i z listu do Dziekońskiej, nie leży jednak wspólny pierwowzór (konkretna osoba), bez wątpienia stanowi ona przejaw antropologicznej postawy twórcy Solo, wyrastającej z koncepcji życia, silnie nasyconej wattkami biblijno-teologicznymi ${ }^{42}$. „A Bóg mój - żywot jest i zmartwychwstanie, / I to jest wszystek cel, choć przez konanie", pisał Norwid w Niewoli (DW-4 55). Z postawy tej wynika trwałe zainteresowanie problematyką rzeczy ostatecznych, do której kluczem - jak zauważyła Izabella Smentek - jest „misterium osoby”43. Portretowy czy quasi-portretowy charakter oblicza kobiety wskrzeszanej na dźwięk „Bożej trąby” uwydatnia ów personalistyczny horyzont oraz Norwidowskie umiłowanie konkretu, które pozwala na to, by „świętemu wychyleniu się za czas dla wieczności” ${ }^{44}$, przeznaczonemu każdemu człowiekowi, nadać rysy nad wyraz indywidualne.

Warto przypomnieć jeszcze inne kompozycje, w których za pomoca środków artystycznych autor Vade-mecum starał się ukazać triumf życia nad śmiercią. Mowa o kilkakrotnie przez niego podejmowanym ewangelicznym temacie wskrzeszenia Łazarza. Bodaj najbardziej przejmujące studium postaci, którą Chrystus ponownie obdarzył tchnieniem życia, Norwid zawarł w powstałej w 1852 r. akwaforcie. Na rycinie tej twarz Łazarza wciąż wydaje się pogrążona w śmiertelnym odrętwieniu, podczas gdy w jego spowitym w całun, ale przedstawionym w pozycji stojącej ciele widoczne sa już pierwsze oznaki życia (il. 8; K-5 432, 434, poz. 1086). W innej, rysunkowej realizacji Łazarz - podobnie jak bohaterka omawianej akwaforty - dopiero podnosi się z grobu, nie przezwyciężywszy w pełni ciążenia śmierci (il. 9; K-4 348, poz. 853). Szczytowy punkt historii Łazarza stanowią słowa Zbawiciela: „Jam jest zmartwychwstanie i żywot; kto w mię wierzy, choćby też umarł, żyć będzie. A wszelki, który żyje a wierzy w mię, nie umrze na wieki” (J 11, 25-26), ściśle przystające do teochrystologicznej eschatologii św. Pawła, za którą Norwid podążał. Zarówno w akwafortach Alleluja I oraz Alleluja II, jak i w przedstawieniach ewangelicznej sceny Wskrzeszenie Łazarza zdecydował się twórca na ukazanie momentu granicznego, tej chwili, w której ostateczna przemiana jeszcze się w pełni nie dokonała, dzięki czemu odbiorca wkracza w każde $z$ wydarzeń w jego kluczowym momencie.

Wypada odnotować, że omówione realizacje plastyczne, które wprost odwołują się do chrześcijańskiej eschatologii, ilustrując nowotestamentowe wyobrażenia wskrzeszenia umarłych, w czytelny sposób nawiązują do tradycji ikonografii chrześcijańskiej. Scena wskrzeszenia Łazarza stanowi w sztuce temat zarówno autonomicznych dzieł, jak i przedstawień należących do cykli ilustrujących życie i cuda Jezusa Chrystusa, przy czym wykształciły się dwa zasadnicze schematy ikonogra-

Całościowe ujęcie Norwidowskiej antropologii zaproponowała R. G a d a m s ka - S e rafin (Imago Dei. Człowiek w myśli i twórczości Cypriana Kamila Norwida. Sanok 2011). Zob. też A. D u n a j s ki, Chrześcijańska interpretacja dziejów w pismach Cypriana Norwida. Lublin 1985 (m.in. s. 153-161). I. S m e n t e k, Myśl eschatologiczna epoki romantyzmu i jej polski przykład-Cyprian Kamil Norwid. „Teologia w Polsce” 2012, nr 1, s. 108. 
ficzne, wyznaczone przez sposób ujęcia sylwetki wskrzeszanego ${ }^{45}$. Akwaforta ukazująca Łazarza w pozycji stojącej, wciąż spowitego w pogrzebowe płótna, wpisuje się w pierwszy schemat, wywodzacy się od najstarszych przedstawień tego tematu z pierwszej połowy III stulecia, znajdujących się w rzymskich katakumbach (np. w tzw. Kaplicach Sakramentów, katakumbach Kaliksta, krypcie pasji, katakumbach Pretekstata) ${ }^{46}$. $Z$ kolei rysunek, na którym Łazarz ukazany jest w pozycji siedzacej, w chwili gdy podnosi się $\mathrm{z}$ grobu, stanowi realizację drugiego schematu, dominującego w malarstwie zachodnioeuropejskim od czasów renesansu ${ }^{47}$. Kilkakrotnie przez Norwida podejmowany temat powszechnego zmartwychwstania ciał stosunkowo rzadko bywa przedmiotem autonomicznych dzieł sztuki, jest natomiast stałym elementem ikonografii Sądu Ostatecznego ${ }^{48}$. Zmartwychwstanie łączy się w tych przedstawieniach $\mathrm{z}$ podziałem na zbawionych i potępionych. Ci pierwsi, ukazani po lewej stronie od widza (po prawej stronie Chrystusa i Michała Archanioła), powstają z grobów, wznosząc ufne spojrzenia ku Zbawcy, a drudzy - przedstawieni po stronie przeciwnej - odwracają się od Chrystusa i oddają się we władanie Księcia Ciemności ${ }^{49}$. Norwidowskie realizacje tematu wskrzeszenia umarłych (akwaforty Alleluja I i Alleluja II oraz rysunki ukazujące postaci unoszące się nad grobami), abstrahujące od nadrzędnego tematu Sądu Ostatecznego, prezentują wyłącznie wizerunki postaci zwracających się ku niebu. Twórca Solo uwzględnił zatem tylko perspektywę wiernych uczniów Chrystusa, budzących się ze śmierci z nadzieją na życie wieczne. $Z$ jednej strony, jest to ujęcie wynikające ze specyfiki kameralnej twórczości plastycznej Norwida, wypowiadającego się najchętniej poprzez

Zob. É. Mâle, La Résurrection de Lazare dans l'art. „Revue des Arts” 1951, nr 1. - A. Zi e m b a, „Wskrzeszenie Łazarza” Carela Fabritiusa $w$ świetle nowych badań nad kręiem Rembrandta. „Biuletyn Historii Sztuki” 1992, nr 1. - S. Ko bi elu s, Wskrzeszenie Łazarza $w$ teologii $i$ ikonografii średniowiecza. Kraków-Tyniec 2016.

46 W najstarszych przedstawieniach występują tylko Chrystus i Łazarz, z czasem scenę tę wzbogaciły postaci kolejnych obserwatorów - zob. B. W r o n i k ow s k a, Picturae sacrae. Motywy ikonograficzne malowidet przedkonstantyńskich $w$ chrześcijańskich katakumbach Rzymu. Lublin 1990, s. 118-121. - J. S. Party ka, La Résurrection de Lazare dans les monuments funéraires des nécropoles chrétiennes à Rome. (Peintures, mosaïques et décors des épitaphes). Étude archéologique, iconographique et iconologique. Varsovie 1993. Ów schemat obowiązuje również w tradycji ikonograficznej Kościoła wschodniego - zob. L. O us pensky, V. Los s ky, The Meaning of Icons. Transl. G. E. H. Palmer, E. Kadloubovsky. New York 1983, s. 175-176. - Kobielus, op. cit., s. 85-87.

47 Np. A. van Ouwater (ok. 1445, Gemäldegalerie, Berlin), A. va n Leyden (ok. 1530, Rijksmuseum, Amsterdam), J. de Riber a (ok. 1616, Museo Prado, Madryt), P. P. Rubens (Musée du Louvre, Paryż), Rembrandt van Rijn (1630-1632, Los Angeles County Museum of Art). Zob. L. Ré a u, Iconographie de l'art chrétien. T. 2: Iconographie de la „Bible”, cz. 2: Nouveau Testament. Paris 1957, s. 727-742. - H. Me u re r, Lazarus von Bethanien. Hasło w: Lexikon der christlichen Ikonographie. Hrsg. E. Kirs c h ba u m. Rom 1971. - B. Iw a s z ki ew icz-Wron ik ow s k a, Łazarz: IV. Ikonografia. Hasło w: Encyklopedia katolicka. T. 11. Lublin 2006.

48 Zob. Réa u, op. cit., s. 386-391. - E. Zaros a, Sąd Ostateczny: III. W ikonografii. Hasło w: Encyklopedia katolicka, t. 17 (2012).

49 Np. Fra Angelico (ok. 1435, Museo Nazionale di San Marco, Florencja), R. van der Weyden (1448-1451, Hôtel-Dieu de Beaune), M. Bu o narroti (1534-1541, Kaplica Sykstyńska, Watykan), P. P. Rubens (1617, Alte Pinakothek, Monachium), J. J ordaen s (1653, Musée du Louvre, Paryż), W. Bla ke (Dzień sądu, ilustracja do poematu R. Blaira The Grave, 1808), P. von Cornelius (1840, kościół św. Ludwika, Monachium). 
fragment, szkic, niewielką scenę figuralna, $z$ drugiej natomiast pozostaje ono w zgodzie ze stanowiącą dla autora Echa ruin nadrzędne źródło inspiracji refleksją św. Pawła, który swą naukę o „końcu” głosił wierzącym jako eschatologię zbawczą, w związku z czym nie poruszał szerzej tematu „potępienia” ${ }^{50}$.

Kreśląc obrazy zmartwychwstania, Norwid opierał się na tradycji ikonografii chrześcijańskiej, na znajomości Pisma Świętego i katechizmu Kościoła katolickiego. Chcąc być postrzegany jako artysta religijny, o czym przekonuje lektura biogramu znanego jako [Autobiografia artystyczna], opracowanego w 1872 r. na potrzeby planowanego słownika artystów polskich (PW-6 556-560) ${ }^{51}$, twórca Solo nie poprzestawał na kopiowaniu utrwalonych schematów ikonograficznych. Nieduży zespół przedstawień powszechnego zmartwychwstania ciał ujawnia poszukująca naturę artysty, skłonność do przekształcania znanych wzorców i wypracowywania własnych rozwiązań. Świadczą o tej skłonności zarówno rysunek z albumu Lenartowicza, na którym wizja eschatologiczna przenika się $z$ realiami XIX stulecia, jak i dwie wersje akwaforty Alleluja, w których powszechne zmartwychwstanie zyskuje rys personalistyczny. Ta linia zgadza się z twórczością poetycką Norwida. Wiersze Do Zesztej..., Śmierć i Sfinks - wszystkie ciążą w stronę ujęcia eschatologicznego. Tematykę spraw ostatecznych, w odróżnieniu od problematyki eklezjalnej, poeta najczęściej kreśli w formie ujęć kameralnych, ograniczonych osobowo. Eschatologia Norwidowska - co pokazuje twórczość plastyczna - unika spektakularnych i wielkich przedstawień sądu, a moment przejścia, jak w Quidamie, celowo ogranicza do skromnej sceny zogniskowanej na osobie.

Jest jednak Norwid także autorem wykonanego $\mathrm{z}$ nietypowym dla niego rozmachem rysunku, którego enigmatyczna treść nie poddaje się łatwo interpretacji ani nawet deszyfracji, aczkolwiek bez watpienia pozostaje w kręgu wyobrażeń eschatycznych (il. 10; K-4 34, poz. 711). Szkic ten, datowany na r. 1859, przedstawia liczna grupe postaci, które w zwartym pochodzie oddalają się w nieokreślonym kierunku. Większość uczestników porusza się dynamicznie, jakby w tańcu, podnosząc ramiona, ale są też osoby, które osłaniając twarze dłońmi niczym w rozpaczy, starają się oddalić od otaczającego je tłumu. Korowodowi przygląa się Tanatos - brodaty mężczyzna ze skrzydłami u ramion, w jednej dłoni ściskający opuszczoną kosę, a w drugiej unoszacy zapaloną potrójną lampę. Za jego plecami siedzi na ziemi spowita w płaszcz kobieta skrzętnie coś notująca w trzymanej na kolanach księdze, opatrzona mocno zatartym, ale wciąż czytelnym napisem „HISTORIA”. Tajemnicza scena zdaje się odwoływać do Norwidowskiej idei „czasów-wypełnienia”, o czym przekonuje nas wizerunek Tanatosa, któremu artysta niejako „odebrał” sprawczą moc i władzę nad ludzkim losem. W tradycyjnych wyobrażeniach grecki bóg trzyma w opuszczonej dłoni zgaszoną i odwróconą pochodnię lub kosę ze skierowanym ku górze kosiskiem (obydwa atrybuty symbolizuja śmierć), podczas gdy Norwid kazał mu wznieść zapaloną lampę o trzech pokaźnych płomieniach, stanowiąca - podobnie jak trzymana w drugiej dłoni bezwładnie opuszczona kosa - zaprzeczenie owej śmierci. Z kolei personifikacja historii na kartach swej kroniki

51 Zob. E. Chlebowska, Szmaragd cesarza Tyberiusza - „prawdziwe” wizerunki Chrystusa $w$ twórczości Norwida. „Studia Norwidiana” t. 36 (2018), s. 117-118. 
zdaje się zapisywać ostatnie chwile przed dokonującym się na jej oczach „końcem dziejów”.

Omówione w niniejszym artykule eschatologiczne obrazy, zwłaszcza wyobrażenia zmartwychwstania umarłych, ukazujące moment, w którym „oścień śmierci” ustępuje tchnieniu wiecznego życia, a człowiek otrzymuje od Najwyższego „nową ciała garstkę w niebie" 52 , ujawniają głęboka wiarę Norwida w chrześcijańską obietnicę ostatecznego pocieszenia. Są również świadectwem ożywionego i wyjątkowo płodnego artystycznie dialogu ze św. Pawłem, podjętego przez poetę w latach pięćdziesiątych XIX stulecia. Dialog ten zaowocował nie tylko pokaźną liczbą utworów literackich - o czym pisał obszernie Marchewka - lecz także wieloma dziełami plastycznymi, odwołującymi się do Pawłowej eschatologii, wedle której Zbawiciel przekształci „ciało nasze podłe, aby się podobne stało chwalebnemu ciału jego” (Flp 3, 21).

\section{ANEKS}

1. C. N orwid, Trzy pokolenia. 1845. Rys. sepią. Bibl. Narodowa, nr inw. R.604. Fot. Bibl. Narodowa.

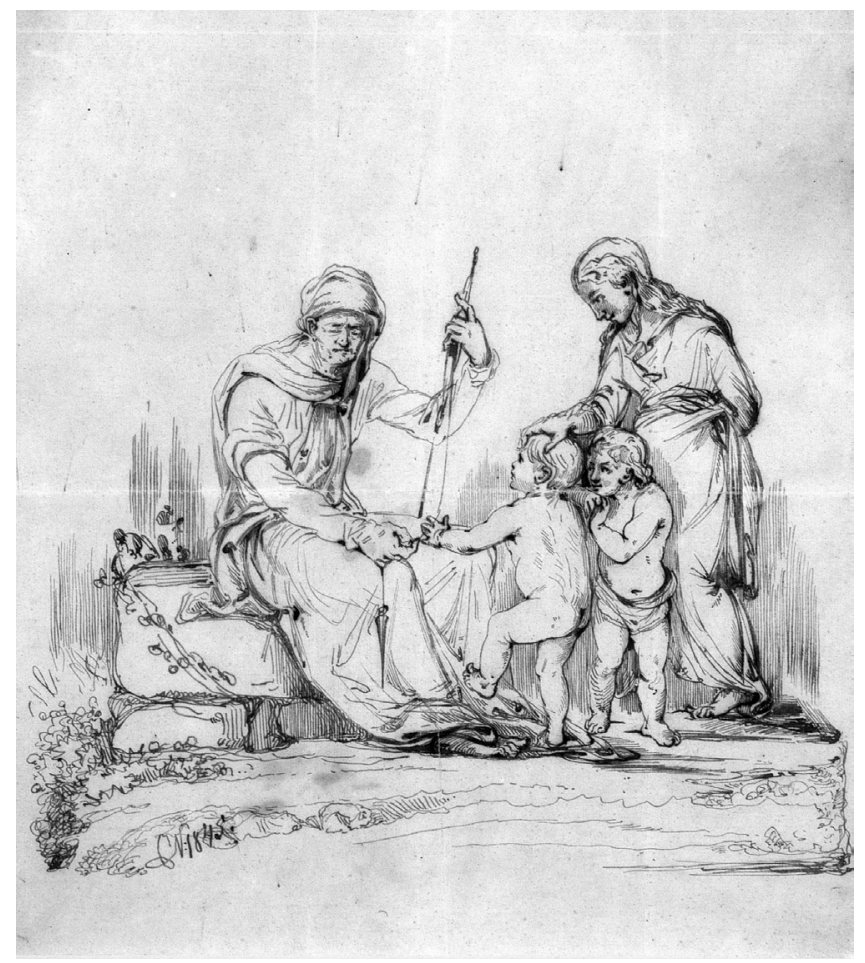


2. C. Norwid, Sześć scen z życia ludzkiego. 1852. Rys. tuszem. Muz. Narodowe w Krakowie, Oddz. Czartoryskich, nr inw. XV Rr.2475. Fot. Muz. Narodowe w Krakowie.

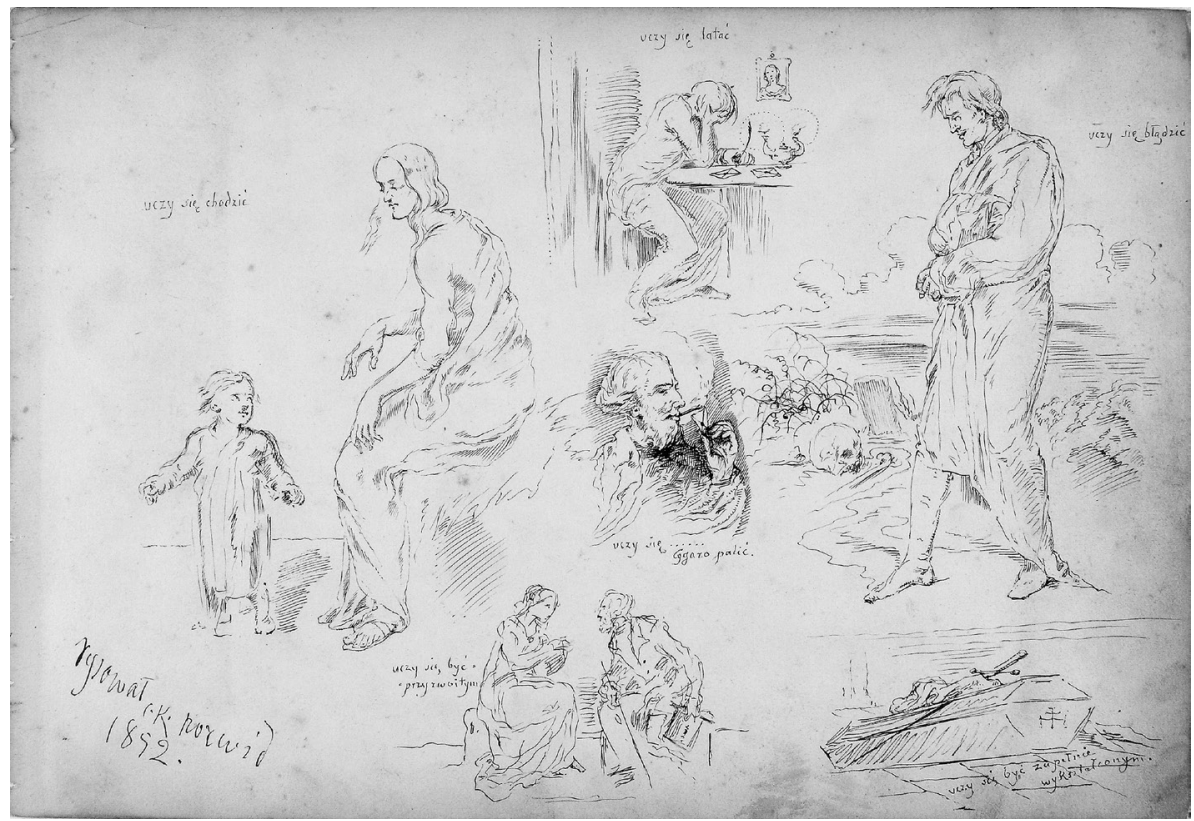

3. C. N orw i d, Dusze ulatujace z mogił II. 1854. Akwarela. Zakład św. Kazimierza w Paryżu. Fot. E. Chlebowska.

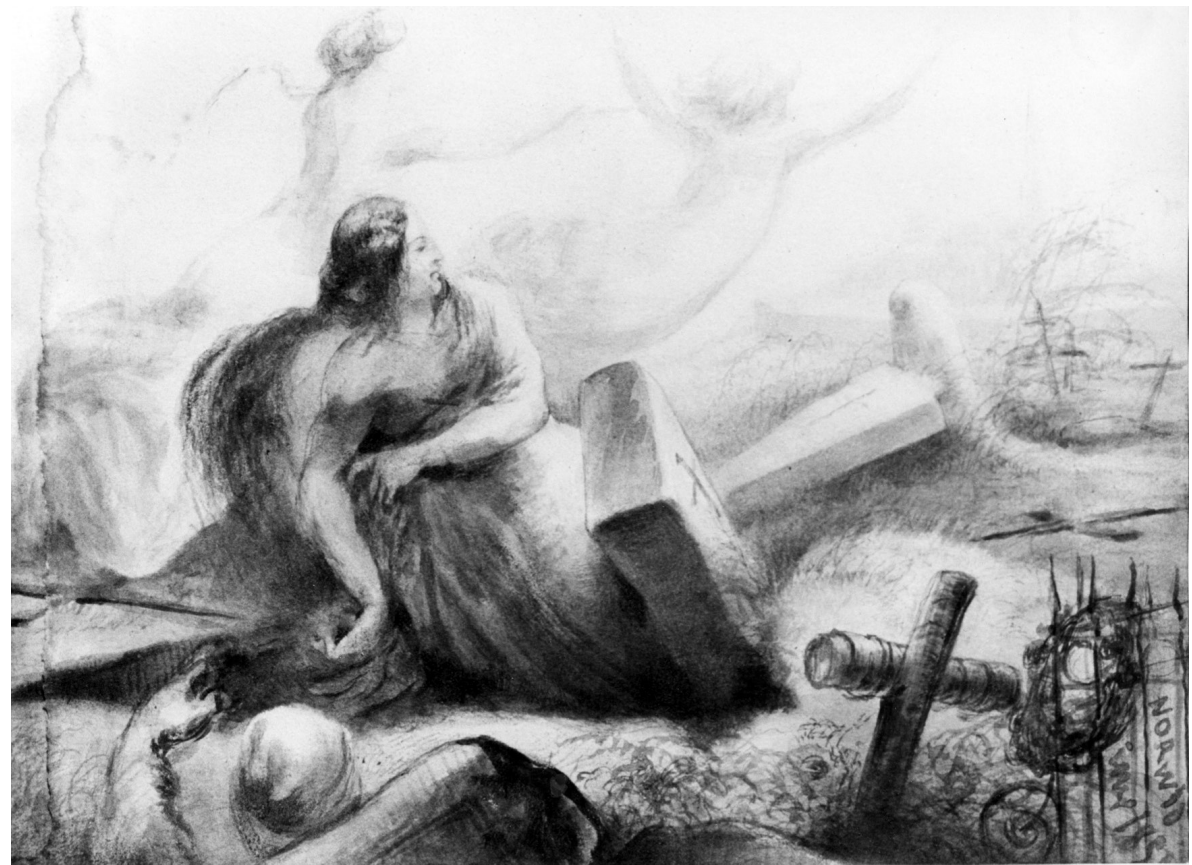

http://rcin.org.pl 
4. C. N orwi d, Dusze ulatujace z mogił I. 1853. Rys. sepią. Muz. Narodowe w Warszawie, nr inw. Rys.Pol.7672. Fot. P. Ligier.

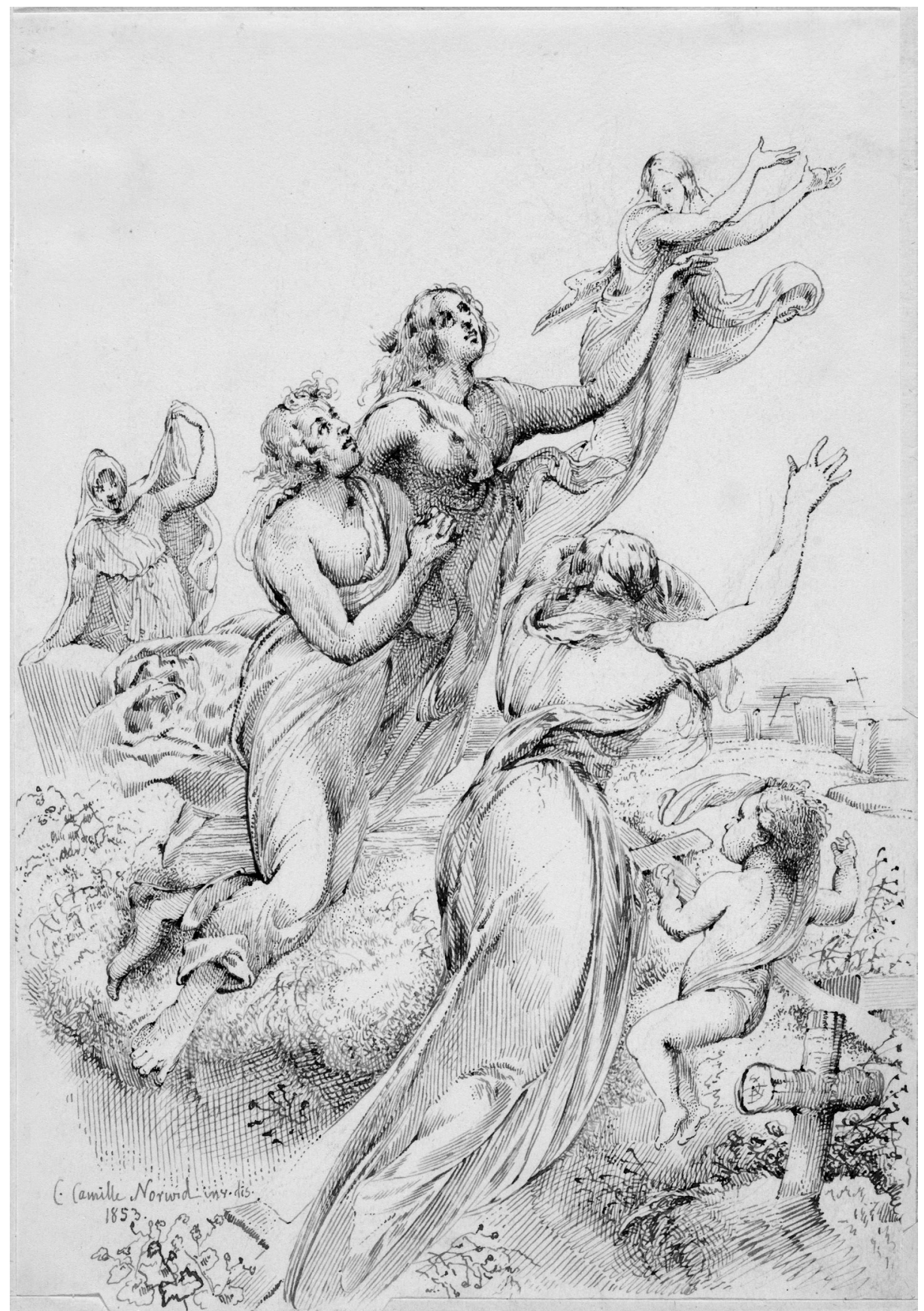


5. C. N orwid, Dusze ulatujace z mogit do nieba. 1853. Rys. tuszem, akwarela. Bibl. Nauk. PAU i PAN w Krakowie, nr inw. BZS.RKPS.2029.19. Fot. Bibl. Nauk. PAU i PAN w Krakowie.

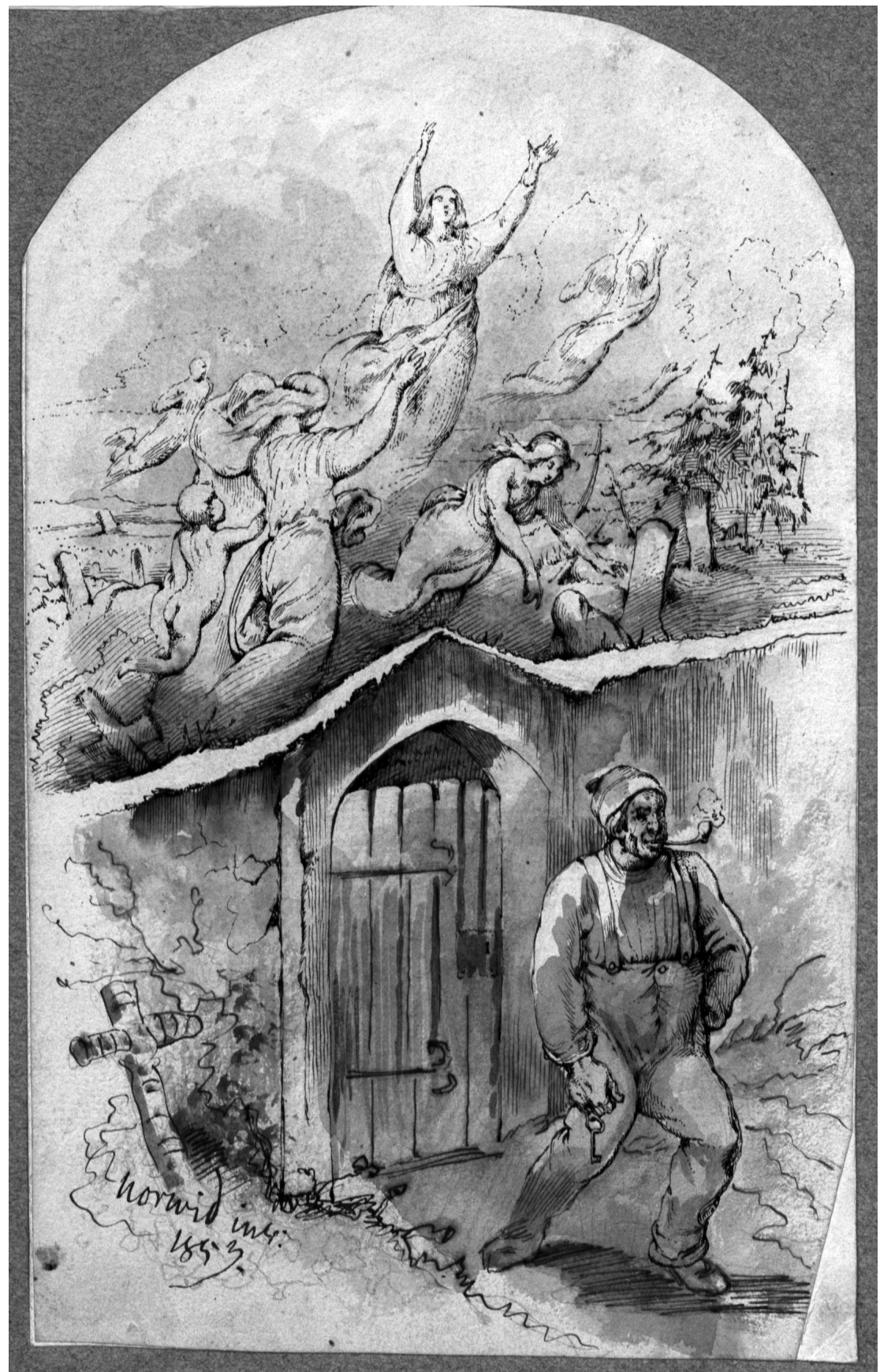


6. C. N orwid, Alleluja I. 1857. Akwaforta, ruleta, akwatinta. Bibl. Narodowa, nr inw. G.4413 (stan I). Fot. Bibl. Narodowa.

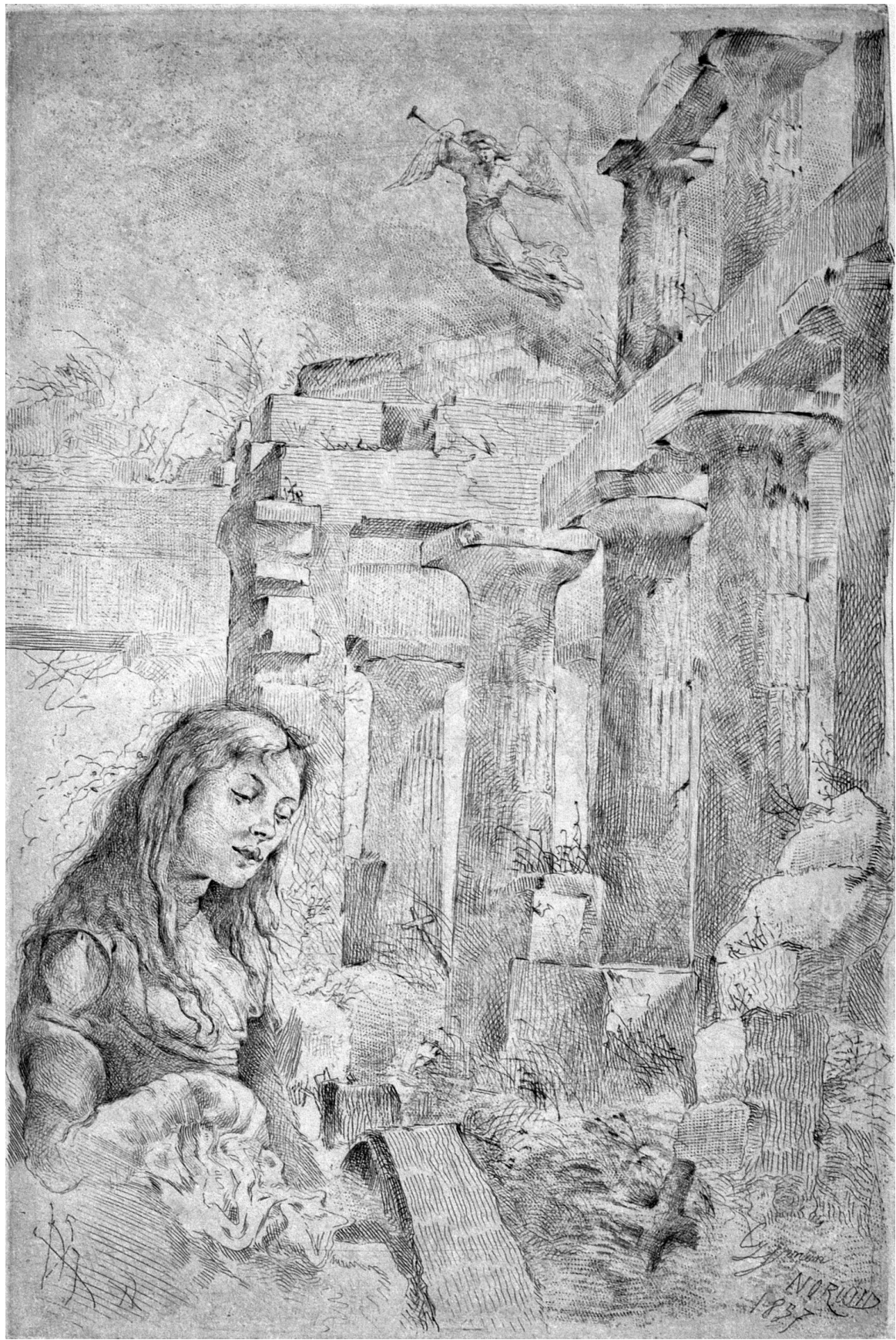


7. C. N orw i d, Alleluja II. 1857. Akwaforta. Muz. Narodowe w Warszawie, nr inw. Gr.Pol.9828/1. Fot. P. Ligier.

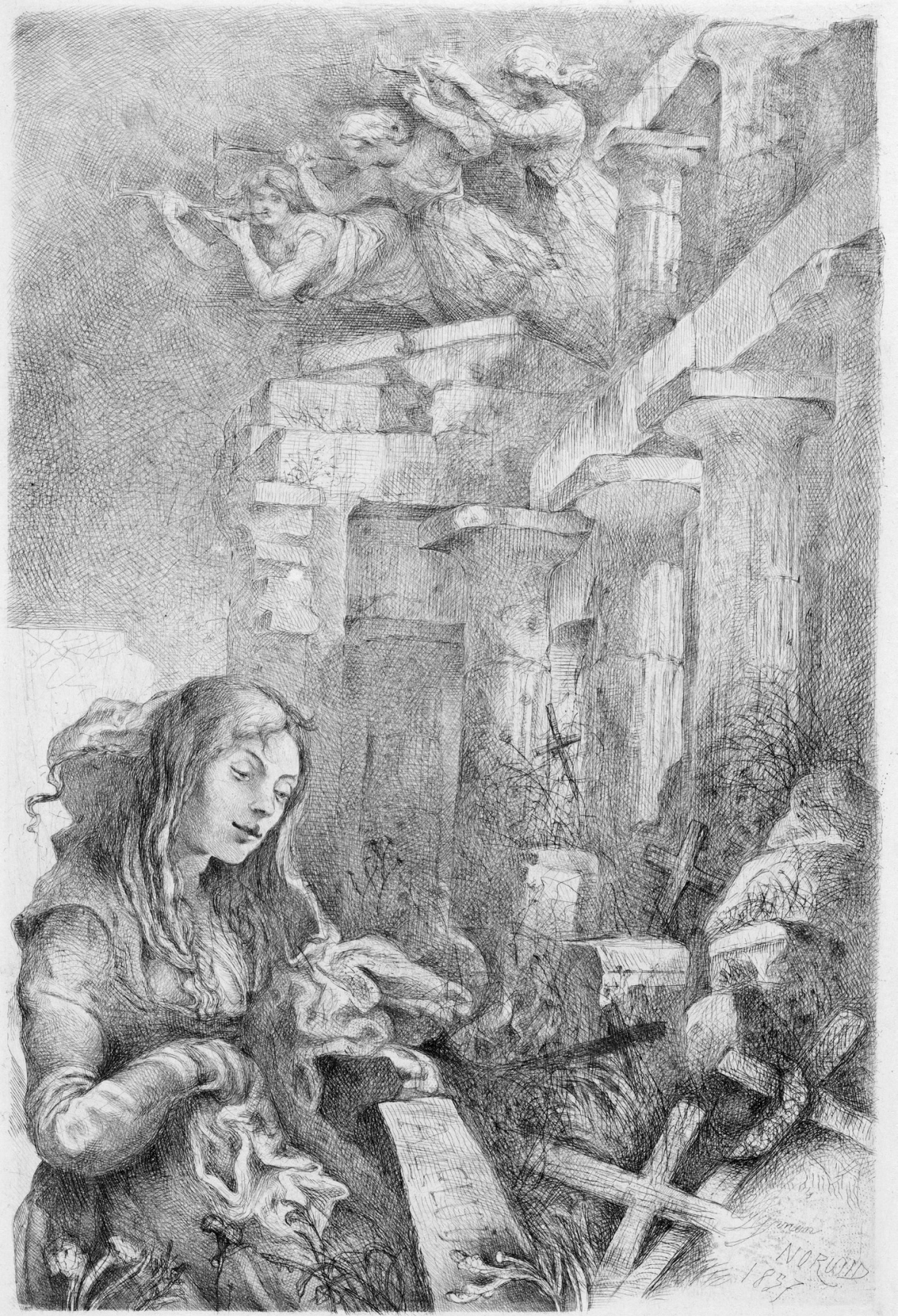


8. C. Norwid, Wskrzeszenie Łazarza. 1852. Akwaforta. Muz. Narodowe w Poznaniu, nr inw. Gł 2386. Fot. Muz. Narodowe w Poznaniu.




9. C. N orwid, Wskrzeszenie Łazarza. 1875. Rys. ołówkiem, akwarela. Bibl. Narodowa, nr inw. R.574. Fot. Bibl. Narodowa.

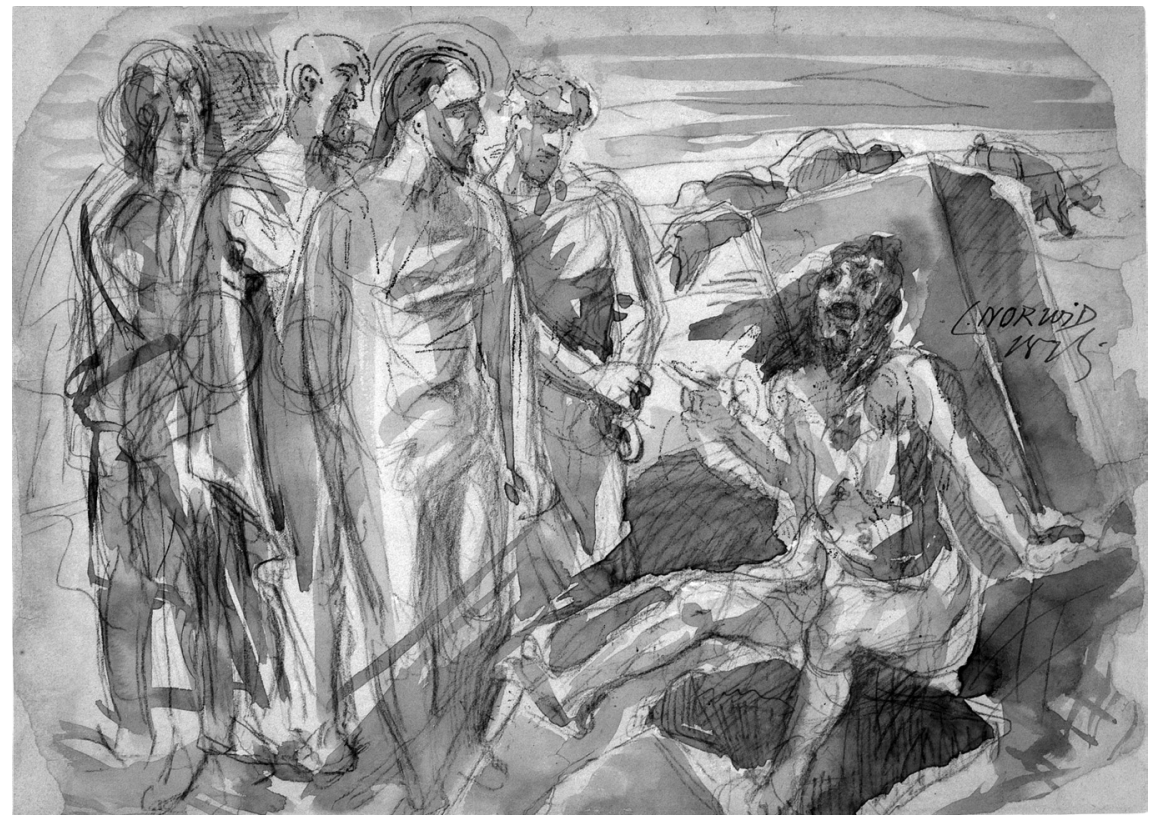

10. C. N orwid, Wizja eschatologiczna. 1859. Rys. tuszem, akwarela. Kolekcja prywatna.

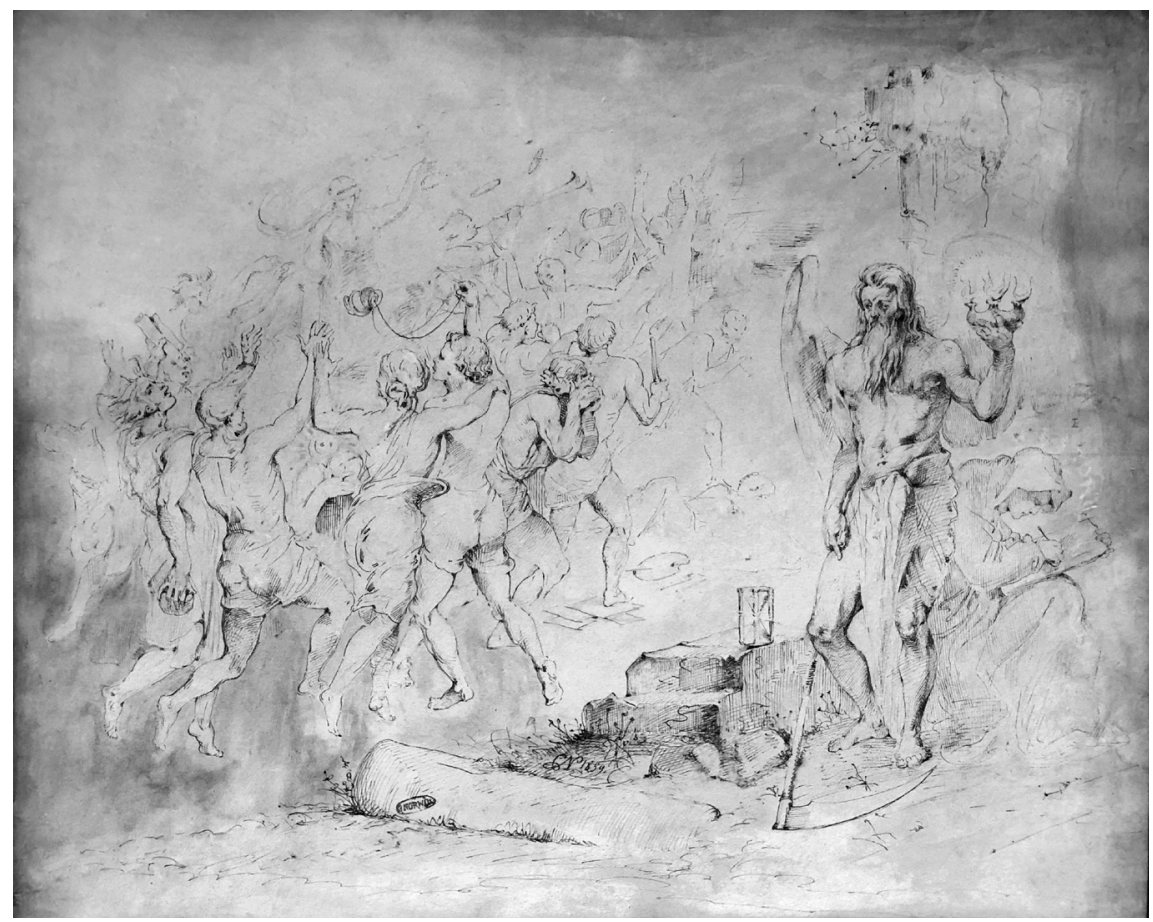

http://rcin.org.pl 


\section{Abstract \\ EDYTA CHLEBOWSKA John Paul II Catholic University of Lublin ORCID: 0000-0001-7814-6323 \\ WHEN "BODY TURNS INTO SPIRIT, AND SPIRIT TURNS BACK TO BODY" ESCHATOLOGICAL PLOTS IN NORWID'S FINE ARTS}

The article refers to the eschatological issues that preoccupied not only Norwid-poet and Norwid-thinker, but also to a large degree complemented his iconography concentrated on a man's life and death. The author of the paper analyses a few Norwid's pictorial and graphical works produced in the 1850s that directly denote the Christian learning of every man's Resurrection at the end of time. A prominent place among the works is occupied by the etching Alleluja (Hallelujah) that displays a personalistic horizon of Norwid's thought and love for the concrete. The analysed pieces, the sources of which are deeply rooted in the readings of the papers by Saint Paul who sketches for Christians the images of eschatological hope, are on the one hand a peculiar profession of faith, while on the other hand a fruit of intensified reflection on the issue to which the poet devoted a text written in a form of a collection of notes, and which was published by Juliusz Wiktor Gomulicki under the title [Zmartwychwstanie historyczne] ([Historical Resurrection]). 